\title{
Bitenosh's Orgasm, Galen's Two Seeds and Conception Theory in the Hebrew Bible
}

\author{
Laura Quick \\ University of Oxford, Oxford, UK \\ laura.quick@theology.ox.ac.uk
}

\begin{abstract}
In the Genesis Apocryphon, Lamech worries that his son is illegitimate and accordingly confronts his wife about her fidelity. Bitenosh answers these accusations with a surprising response: she asks her husband to recall the sexual pleasure that she experienced during their intercourse. Scholars have clarified this rhetorical strategy by connecting the episode to Greco-Roman theories of embryogenesis, in which a woman's pleasure during intercourse was taken to indicate conception. While this provides a convincing explanation for Bitenosh's argumentation, in this essay I argue that rather than deriving these ideas from the Greco-Roman world, the conception theory which informed the Genesis Apocryphon is in fact consistent with notions that can already be found in the Hebrew Bible and the wider ancient Near East. By exploring the concept of conception in biblical and ancient Near Eastern texts, I uncover a belief in the necessity for female pleasure during intercourse as well as the existence of female "seed." These ancient authors were able to develop and promote significant reflections upon medical issues such as conception, and this is recalled in Bitenosh's speech. This essay therefore has significant implications for understanding concepts of sex and conception in the Genesis Apocryphon, as well as in the Hebrew Bible and the wider ancient Near East more generally.
\end{abstract}

\section{Keywords}

Genesis Apocryphon - Aristotle - Galen - conception theory - ancient medicine Hebrew Bible - Ancient Near East 
The Genesis Apocryphon provides an interesting detail concerning the birth of Noah. Lamech worries that his son is illegitimate, born of the Watchers, and accordingly he confronts his wife about her fidelity. Lamech also suspects that Noah's conception was of angelic origin in 1Enoch 106-107, and much of the work on this passage has focussed on clarifying the relationship between these two accounts. ${ }^{1}$ But the specifics of the conversation between husband and wife in 1QapGen ar 2:9-18 have no counterpart in any other text. Uniquely in the Genesis Apocryphon, Bitenosh ${ }^{2}$ is provided the chance to answer the accusations of infidelity:
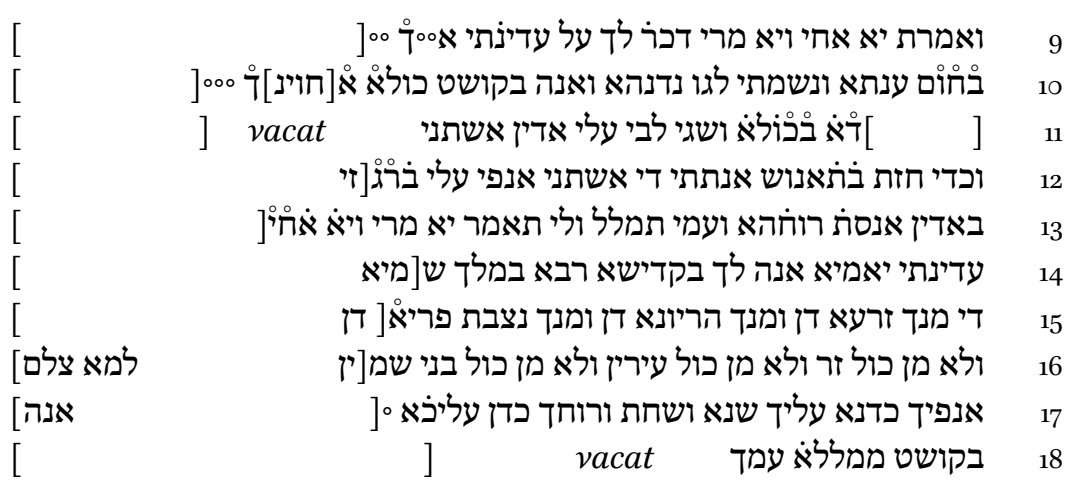

9 And she said, "O my brother and my husband, recall for yourself my pleasure $^{3} \ldots[$ [ ]

1 For a comparison of the two accounts, see especially Machiela, "Genesis Revealed," $205^{-21}$; and Stuckenbruck, "The Lamech Narrative," $5{ }^{8-77}$. Some of this work has been particularly focussed upon clarifying the priority of the two texts. Considering the Genesis Apocryphon to be earlier is Eshel, "The Imago Mundi," 111-31. Arguing for the opposite order of priority is Kugel, "Which is Older," 257-94.

2 On the vocalization of Bitenosh, see Fitzmyer, The Genesis Apocryphon, 82-83. Bitenosh is not otherwise named in the account of Noah's birth from 1 Enoch, and the only other work which refers to her by name is Jubilees (4:28). However, Jubilees does not contain a reference to Noah's birth.

3 Almost all commentators render the Aramaic עדינתי in 11.9 and 14 as something like "my (sexual) pleasure." One dissenting voice is that of Beyer (Die aramäischen Texte, 652), who provides the translation "Schwangerschaft." While in Palestinian Aramaic עדי can mean "to be(come) pregnant" (Sokoloff, A Dictionary of Jewish Palestinian Aramaic, 396-97), since l. 10 explicitly refers to Bitenosh's panting breath as well as the "heat" of intercourse (see n. 4, below), עדינתי here must refer to specifically sexual pleasure. Indeed, as we shall go on to see, "heat" can be employed euphemistically to refer to orgasm in ancient Near Eastern literature. The reference to panting breath, lit. "my breath in the midst of its body/sheath," also has explicitly sexual overtones, as noted already by Fitzmyer: "the panting breath like a sword moving back and forth within" (The Genesis Apocryphon, 87). 
10 in the heat of the moment, ${ }^{4}$ and my panting breath! I [am telling] you everything truthfully ... [ ]

$11 \quad[\quad]$... entirely." Then my mind wavered greatly within me. ${ }^{5} \quad$ vacat

12 Now when Bitenosh my wife saw that my demeanour had changed because of [my] ang[er

Then she controlled her emotions and continued speaking with me. She was saying to me, "O my husband and my brother, [

my pleasure. I swear to you by the Great Holy One, by the King of $\mathrm{He}[$ aven

that this seed is from you, and from you this conception, and from you the planting of this fruit [

and not from any stranger, nor from any of the Watchers, nor from any of the sons of Hea[ven. Why is the appearance of]

am speaking truthfully with you." 6

Thus, in order to defend the legitimacy of her son, Bitenosh recalls her sexual pleasure during intercourse. Yet surprisingly few commentators have subjected this rhetorical strategy to sustained analysis. George Nickelsburg has connected the episode to what he calls a "psychologizing interest" in the emotions of the characters in the Genesis Apocryphon, although as he notes, "[ $t]$ he point is a bit obscure. The issue is not whether Lamech and his wife have been to bed together, but whether this child was conceived under other circumstances." Thus, for Nickelsburg, while "obscure," the reference to Bitenosh's pleasure has been added in order to develop the account of her psychological distress. Therefore as a rhetorical strategy to prove Noah's paternity, Bitenosh's recol-

4 Literally, "in the heat of time." However, Aramaic ענתא can mean not only "time" but also "sexual intercourse," for example in Tg. Onq. Ex 21:10, where a husband is commanded not to withhold from his wife "her provision, her covering, or her ענתא," which must refer here not to "time" but to the husband's marital duty toward his wife. See Jastrow, Dictionary of the Targumim, 1097. Accordingly, contra Machiela's translation, we might interpret this verse from the Genesis Apocryphon to refer to the "heat of intercourse." Indeed, if the term ענתא was to refer to "time" here in 1QapGen ar 2:10, this would be to the abstract conception of time rather than to a specific moment, which would undermine Bitenosh's larger rhetorical strategy in recalling the moment of conception.

5 On the semantics of the description of Lamech's fear, see Quick, "Lamech's Change of Mind," $53^{-66 .}$

6 GapGen ar 2:9-18. For the text and translation, see Machiela, The Dead Sea Genesis Apocryphon, $35^{-36}$.

7 Nickelsburg, "Patriarchs Who Worry," 143. 
lection falls flat. William Loader has discussed the episode in the context of his consideration of attitudes to sexuality at Qumran, arguing that Bitenosh's reply assumes that during pregnancy, sexual intercourse would cease-thus she refers to the intercourse through which Noah was conceived, "many months previously." ${ }^{8}$ But again, this does not really prove the paternity of the child.

More recently, Ida Fröhlich and Pieter van der Horst have separately suggested connecting the episode to ancient theories of spermatogenesis and embryogenesis, in which a woman's pleasure during intercourse was taken to indicate conception. ${ }^{9}$ In so doing, they have provided a brilliant solution to the problem: Bitenosh's argumentation recalls her orgasm during marital intercourse to prove that this was the time at which Noah was conceived. Fröhlich connects the passage to Greek medical traditions of the fourth century ВСЕ, in particular the Hippocratic writings. She finds similarities in the language of the Genesis Apocryphon and the Greek medical texts, and hence argues that the author of the Apocryphon had a "good familiarity" with various branches of contemporary Greek medical writing. In this context, she notes that ancient Near Eastern medical texts "do not say much about the theory of conception." ${ }^{10}$ Van der Horst surveys a wider pool of material than Fröhlich, considering medical texts covering the period from roughly 5 Оо вСЕ to $200 \mathrm{CE}$, and concluding that the author of the Apocryphon was acquainted with the double seed theory associated in particular with the medical writer Galen. ${ }^{11}$ In support of this, van der Horst recalls other texts from the Dead Sea that seem to betray Greek medical knowledge, such as the physiognomic texts that have been extensively unpacked by Mladen Popović. ${ }^{2}$ On the other hand, he considers and then rejects the possibility that these ideas could be found in earlier ancient Jewish literature, in particular the Hebrew Bible. ${ }^{13}$ Thus, despite differences in

8 Loader, The Dead Sea Scrolls on Sexuality, 139, 290, 352.

9 Fröhlich, "Medicine and Magic," 177-98; van der Horst, "Bitenosh's Orgasm," 613-28.

$10 \quad$ Fröhlich, "Medicine and Magic," 177.

11 Albeit Galen, who lived in the first century CE, post-dates the composition of the Genesis Apocryphon. (Fröhlich's attribution of Galen to the third century вСЕ is surely a mistake. See ibid., 187.) On the dating of the Apocryphon, see Machiela, The Dead Sea Genesis Apocryphon, 131-42. Though the manuscript evidence of the Apocryphon may be dated by palaeography and radiocarbon methods to the first century все, because of its dialect and its relationship to Jubilees and to other Aramaic works, we may plausibly move the dating of the composition of the text to the second century вСE. Galen is thus recalled in van der Horst's treatment as the most famous proponent of theories and ideas that significantly pre-date his lifetime.

12 See Popović, Reading the Human Body; van der Horst, "Bitenosh's Orgasm," 627 n. 45; idem, "Early Jewish Knowledge of Greek Medicine," 103-14. van der Horst, "Bitenosh's Orgasm," 62o, 626 n. 42. 
the specifics of their argumentation, both commentators refute the possibility that the theory of conception which informs the Genesis Apocryphon can be found in earlier biblical or ancient Near Eastern texts, and instead attribute first-hand knowledge of Greco-Roman medical writings to the authors of the Apocryphon.

I find the proposal that Bitenosh's orgasm is informed by a theory of embryogenesis in which the female orgasm was necessary for conception to provide a highly satisfying solution to understanding Bitenosh's argument. Nevertheless, rather than deriving these ideas from the Greco-Roman world, in this paper I consider the possibility that the Genesis Apocryphon could be informed by notions found already in the Hebrew Bible and earlier ancient Near Eastern literature. Thus, contra Fröhlich and van der Horst, the theory of conception that underlies the Genesis Apocryphon cannot only be explained by the transmission of Greco-Roman medical tractates into the ancient Jewish milieu. Instead, the Apocryphon may simply reflect common ideas concerning conception held already by the authors of biblical literature, where these ideas developed separately from and in parallel to the Greco-Roman discourse. I begin by considering the Greco-Roman debates favoured by Fröhlich and van der Horst, exploring the connections they observe between these writings and the Apocryphon. Finding these connections to be general rather than specific, I turn to uncover conception theory in the Hebrew Bible, arguing that similar views on the necessity for female pleasure during intercourse as well as the existence of female seed can already be found in biblical texts. This is consistent with the wider ancient Near East, although dissenting and alternative views on the topic are also evident. Thus, in matters of female sexuality and conception, the Genesis Apocryphon is consistent with earlier biblical and ancient Near Eastern theories. The authors of the Hebrew Bible and ancient Jewish literature were able to develop and promote significant reflections upon medical issues such as conception, and this is recalled in Bitenosh's speech.

\section{1 \\ Conception Theory in Greco-Roman Medical Writing}

For many commentators of Greco-Roman medicine, the problematics of conception theory can be reduced to a debate between two competing views, embodied by Aristotle and Galen. ${ }^{14}$ The former favoured preformationism,

14 On conception theory in Pre-Socratic writings, see Lesky, Die Zeugungs- und Vererbungslehre der Antike. 
which attributes all of the relevant genetic material required in conception to one parent. In the context of antiquity, this was almost always considered to be the father. Thus, though acknowledging female contribution to conception, Aristotle nevertheless credited the active principle of a living being, $\pi \nu \varepsilon \hat{\jmath} \mu \alpha$, to the father's semen. The female's contribution instead stems from her menstrual blood:

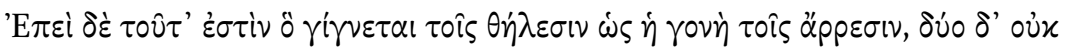

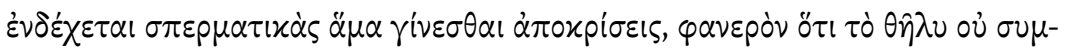

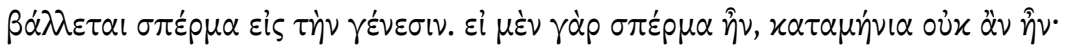

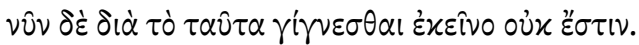

Now it is impossible that any creature should produce two seminal secretions at once, and as the secretion in females which answers to semen in males is the menstrual fluid, it obviously follows that the female does not contribute any semen to generation; for if there were semen, there would be no menstrual fluid; but as menstrual fluid is in fact formed, therefore there is no semen. ${ }^{15}$

The menstrual blood thus provides the passive matter out of which the embryo is formed - through the informing action of the male semen..$^{16}$ Therefore, since menstrual fluid appears quite independently of sexual activity, females differed from males in that neither pleasure nor seminal ejaculation were necessary for conception. ${ }^{17}$ On the other hand, the theory of pangenesis attributes a role to both the male and female in conception. In this context, the "dual seed" theory argued that mother and father both produced and contributed sperm. The greatest advocates of this theory are to be found in the Hippocratic writings and in Galen. The Hippocratic work On the Generating Seed and the Nature of the Child offers as proof of dual seed the fact that both men and women experience pleasure during intercourse, linking this to the discharge of semen. ${ }^{18}$ The two seeds provide identical matter drawn from the entire body, with the sex

\footnotetext{
15 GA 727a26-31. For the text and translation, see Peck, Aristotle, 96.

16 For the language of "active" versus "passive" male and female roles in Aristotle's conception theory, see Presti, "Informing Matter," 932-33.

17 In $H A$ iii 19, Aristotle notes that females conceive without pleasure in intercourse "very often."

$18 \mathrm{~J} 4 \cdot 3=\mathrm{Li} 4764$. A variety of earlier writers also espoused the dual seed theory, such as Eurymachus, Pythagoras, Democritus, Epicurus, and Hippo. See Boylan, "The Galenic and Hippocratic Challenges," 87 .
} 
of the foetus determined by the hot or cold found in its environment. ${ }^{19}$ It is presumably this link between the language of "heat," sex and conception that Fröhlich connects to Bitenosh's speech in the Genesis Apocryphon, thus arguing that the author knew of similar Greek medical tractates. ${ }^{20}$

Galen's views on conception take on features of both the Hippocratic and Aristotelian arguments. ${ }^{21}$ Thus as in the Hippocratic view, Galen attributed semen to women. In fact, through his observation of the ovaries and fallopian tubes, Galen thought he had actually spotted this. ${ }^{22}$ However, Galen was also influenced by Aristotle, thus in spite of arguing for the existence of female sperm he nevertheless saw the female's role as less substantial than the male. ${ }^{23}$ Even so, because of his attribution of semen to women and therefore insistence upon the achievement of female orgasm in conception, Galen is sometimes taken to be more "feminist" than Aristotle. ${ }^{24}$ On the other hand, Sophia Connell cautions against these kinds of evaluations: by attributing semen released during sexual climax to both sexes, Galen takes sexual desire to be of one universal type, "corresponding to the structures and experiences of the male body."25 Accordingly, the ovaries produce "female semen" impelled to the womb as an ejaculatory climax during intercourse in the manner of the male ejaculation.

It is worth remembering that the "debate" between Aristotle and Galen concerning the existence of female semen itself derives from Galen's own posturing, who in the incipit to his On Semen couched his argument in relation to the earlier thinker. ${ }^{26}$ This image of the two scientific rivals became embedded in the Middle Ages, when Aristotle was depicted as the "enemy" of observationally grounded scientific progress, in contrast to Galen-never mind of course that the female is not an inverted male, and that the ovaries do not produce semen, despite Galen's claim to have observed a "thick seminal fluid" there. ${ }^{27}$ There-

$19 \quad \mathrm{~J} 6.1=\operatorname{Li} 4786$.

$20 \quad$ Fröhlich, "Medicine and Magic," 177.

21 Though explicitly connecting his theory to Aristotle, Galen may also have been informed by the first century вСЕ Roman writer Lucretius, who considered the possibility of female semen in De rerum natura. See Blayney, "Theories of Conception," 231-33.

$22 \quad K$ IV 634-5.

$23 \quad K$ IV 516.

24 Thus, commentators have implied that the Galenic theory improved female lives and/or status. See e.g. McLaren, "The Pleasures of Procreation," 341; and Rouselle, Porneia, 323-41.

25 See Connell, "Aristotle and Galen," 405-27. On the one body/two gender approach to sexuality, see Laqueur, Making Sex.

$26 \quad K$ IV 512.

$27 \quad K$ IV 594, 600-1. Modern commentators similarly impressed with Galen's claims for the observational method have attempted to get Galen off the hook in this respect, thus Michael Boylan writes that Galen here "mistook a mucous discharge (common in the 
after these two competing theories provided the theoretical framework for the embryological debate right up until the first half of the seventeenth century. ${ }^{28}$ It is not surprising therefore that Fröhlich and van der Horst have favoured the Greco-Roman discourse as a source for the conception theory which informed the Genesis Apocryphon. Nevertheless, there is nothing specific to the Apocryphon beyond the general idea of female pleasure in conception that would suggest connecting it to any specific thinker or text from the Greco-Roman milieu. Even Fröhlich's promotion of the language of "heat" shared between the Apocryphon and the Hippocratic writings is hardly conclusive. Indeed, the Apocryphon actually seems to promote the opposite perspective in this regard. According to the Greek idea, the male seed was linked with the principles of hot and dry, and the female with cold and moist, ${ }^{29}$ therefore it would be surprising for Bitenosh to recall "heat" in the context of her release of seed if it is indeed these Greco-Roman ideas that she is gesturing to. On the other hand, as we shall go on to see in the following, in ancient Near Eastern literature "heat" can be used as a euphemism for sexual pleasure, which is exactly how the Aramaic בחום ענתא, "in the heat of intercourse," functions in l. 10 of the Apocryphon: the phrase occurs in parallel to עדינתי, "my (sexual) pleasure" (l. 9). By focussing primarily upon the Greco-Roman writings, commentators have failed to explore the biblical and ancient Near Eastern theories of conception which may have informed the writers of the Genesis Apocryphon.

uterine tract) for female seed." See "Galen's Conception Theory," 62. But as Sophia Connell argues, this disregards the fact that Galen claims to not only have observed this fluid, but to also have observed the ovaries full of the fluid prior to intercourse, and empty afterwards - a biological impossibility. Galen's perceptions here have been influenced by what he expected to see. See "Aristotle and Galen," 412. On the reception of Galen in the Middle Ages, see ibid., 406-8.

28 So Presti, "Informing Matter," 930.

29 Boylan, "The Galenic and Hippocratic Challenges," 86. These ideas in fact go back to Aristotle. On the distinction between the genders in the thought of Aristotle, see Merleau, "Bodies, Genders and Causation," 135-51.

30 On the translation of עדינתי as "sexual pleasure," see n. 3. On the translation of ענתא as "intercourse," see n. 4. In 4Q270 2 ii 15-16, the expression מקיץ דם, "heat of blood," may refer to sexual pleasure; the larger context of the verse is concerned with sex and reproduction. See Loader, The Dead Sea Scrolls on Sexuality, 139. Alternatively, Elisha Qimron (The Dead Sea Scrolls, 1:23) has suggested reading the line in question as מקוץ דם, "from the ceasing of blood," i.e., the interruption of menstruation. 
Unlike the Greco-Roman writers, the authors of the Hebrew Bible provide no systematic treatment of the topic of conception. Nevertheless, the Hebrew Bible does evidence a variety of ideas and beliefs about the process of human reproduction. Unsurprisingly, God is intimately involved in conception. Jeremiah 1:4-5 claims that Yahweh knew the prophet "before I formed you in the womb." ${ }^{31}$ Yet beyond divine intervention, clearly the authors of biblical literature understood that sex was also a key component in procreation. ${ }^{32}$ The word זרע has the primary meaning "seed" in the context of the propagative part of a plant (e.g. Gen 1:11). However, it can also refer to the "seed" of man, which is to say, to semen. This is how it is utilized in the purity laws of Leviticus 15, where it occurs in the context of seminal emissions (v. 16, 17, 18, 32). ${ }^{33}$ Related to this semantic domain, זרע can also be used in the sense of "offspring" or "progeny."34 This sometimes creates problems in interpreting references to זרע. In 1QapGen ar 2:1, for example, זרע could mean either "semen" or "offspring," referring to the infant Noah. However, since the term occurs in parallel to הריאת, "conception, pregnancy," the former meaning is probably to be preferred, and indeed, elsewhere in this text the infant Noah is referred to as עולימא, "the youth" (1. 2). Thus, Lamech is specifically worried that the conception of Noah is the result of semen stemming from the Watchers. This connection between "semen" and "progeny" clearly shows that conception was acknowledged to result from the

31 On the significance of the involvement of the deity with the prophet even prior to conception, see Flynn, Children in Ancient Israel, 45-50.

32 Thus in Gen 4:1, the conception of Cain is linked to a sex act: "Now the man knew his wife Eve, and she became pregnant and gave birth to Cain." Hebrew ידע, "to know," is frequently employed as a euphemism for sexual intercourse in biblical literature. See WarrenRothlin, "Euphemism and Bible Translations," 865-69. The perceived dissonance between the necessity for sexual intercourse alongside the promotion of God in the context of conception may be voiced in the continuation of the verse in Gen 4:1: "Then she said, 'I have created a man just as the Lord did!" The Hebrew reads את־יהוה. The particle את is not the direct object marker but the preposition "with" (cf. LXx). This could be translated with the sense of "with the help of" (cf. NEB, NIV, NRSv), or "like, equally with, in common with" (see e.g. Lev 26:39; Isa 45:9; Jer 23:28; cf. the NET translation). Given the context of the story, in which Adam and Eve acquire a knowledge which makes them equivalent to God, the latter translation is to be preferred. This is therefore not an acknowledgement that conception is ultimately divine (contra Stiebert, "Human Conception in Antiquity," 215), but rather a reflection of the significance of the knowledge of human sexuality in the context of (pro)creation.

33 See also Lev 19:20; 22:4; Num 5:13, 28, where it occurs together with the cognate verb in the niphal.

34 Gen 3:15; 7:3; 13:6; 16:10; 22:17, 18; 26:3, 4, 24; Ezra 2:59; 9:2. 
emission of sperm. Indeed, Onan spills his זרע on the ground when he wishes not to conceive with Tamar (Gen 38:9).

Related to this connection between semen and progeny, some commentators have argued for preformationist ideas in the biblical theory of conception: conception stems solely from the contribution of the (male) seed. In this context, it is sometimes noted that in Biblical Hebrew it is passive forms of the verb הרה, "to be pregnant," that describe the moment of female conception. ${ }^{35}$ Baruch Levine, for example, argues that there is

no indication in the Hebrew Bible, as far as we can ascertain, that the female contributes a life essence, an egg, to the embryo; the role of the female is entirely that of nurturer. The seed is provided by the male, and it grows inside the womb. ${ }^{36}$

Yet biblical texts dealing with infertility relate this primarily to women rather than to men, ${ }^{37}$ implicitly indicating the role of the female in conception. Part of the problem is that few commentators have subjected the concept of the female contribution to conception in the Hebrew Bible to sustained analysis. One exception is Johanna Stiebert, who suggests that menstrual blood be associated with procreatory powers. ${ }^{38}$ Both menstrual blood and seminal emissions entail purification rituals in Leviticus 15, and Stiebert argues that these regulations stem not from a concept of these emissions as impure, but rather due to a concern for their role in the creation of life. ${ }^{39}$ In her analysis, Stiebert explicitly interprets the biblical text in light of Greek medical writings, where as we have seen, Aristotle also understood the female contribution to conception to stem from menstrual blood. ${ }^{40}$ Yet the regulations concerning seminal emissions and menstrual blood in Leviticus 15 can perhaps be better explicated in light of the

35 See Stol, Birth in Babylonia, 6.

36 Levine, “'Seed' versus 'Womb'” 341-42. See also Rashkow, Taboo or Not Taboo, 76: Sarah "supplies nothing of her essential being to her son ... and is merely the vehicle ... Woman is the soil in which male seed is planted."

37 See especially Moss and Baden, Reconceiving Infertility, 1-20; and Henriksen Garroway, Growing Up in Ancient Israel, 28.

38 Another notable exception is the masterful study of Cynthia Chapman, who considers the kinship-forming properties of breast milk. See "Oh That You Were Like a Brother to Me," 141. Nevertheless, this focus on breastfeeding sees the female role in ethnogenesis relegated to a purely post-birth event.

39 See Stiebert, "Human Conception in Antiquity," 221; cf. Whitekettle, "Levitical Thought," 376-91, on whose work Stiebert draws here.

Stiebert, "Human Conception in Antiquity," 222. 
preference in biblical and especially Priestly literature for bodily "wholeness," where wholeness of the body is equivalized with holiness. In this context, bodily events in which the integrity of the body is threatened (genital emissions, sex, skin disease, childbirth, and so on) are subject to strict ritual regulation. ${ }^{41}$

In fact, there are hints within biblical literature that the writers held views that we might better associate with pangenetic theories of conception, in particular the idea that the woman contributes a "seed" of her own. We have already seen that "semen" and "offspring" are equivalized in Biblical Hebrew through the term זרע. But this term does not only designate the relationship between a father and his biological offspring. "Seed" is used to describe Eve's collective offspring in Gen 3:15; Hagar's child in Gen 16:10; and Rebekah's offspring in Gen 24:60. ${ }^{42}$ These references provide an interpretative framework for understanding an enigmatic reference to female conception in Lev 12:2:

דבר אל־בני ישראל לאמר אשה כי תזריע וילדה זכר וטמאה שבעת ימים כימי נדת דותה

תטמא

Tell the Israelites, "When a woman produces seed and bears a male child, she will be unclean seven days, as she is unclean during the days of her menstruation."

The verb זרע, "to sow seed," occurs here in the active hiphil stem, with the literal meaning "to produce seed."43 Elsewhere, when a form of זרע means "to become pregnant," the passive niphal form is used. ${ }^{44}$ What to do with this unusual usage has perplexed commentators, both ancient and modern. The Samari$\tan$ Pentateuch corrects the verb to the niphal, and this is followed by the LXX translation: $\ddot{\tau} \tau \varsigma \xi \dot{\varepsilon} \dot{\alpha} \sigma \pi \varepsilon \rho \mu \alpha \tau \iota \sigma \theta \hat{\eta}$, "if she is impregnated ..." The $\mathrm{KJV}$ is ambiguous ("if a woman hath conceived seed ..."), however other modern translations favour the LXX reading, converting the active verb into a passive construction. ${ }^{45}$ While John Hartley follows the мт according to the principle of Lectio difficil-

41 The identification of the importance of bodily wholeness and integrity in Israelite thought goes back to Douglas, Purity and Danger, esp. $5^{1-52}$. For a discussion of her influence in the context of the Priestly source, see Olyan, "Mary Douglas's Holiness/Wholeness Paradigm," $1-8$.

For further discussion of the female seed in Hebrew literature, see Erbele-Küster, Body, Gender, and Purity, 106-9.

43 The hiphil of זרע found elsewhere only in Gen 1:11-12 for plants "producing" their own "seed."

44 See Nah 1:14; and Num 5:28, where it is used explicitly of a woman.

45 See e.g. NIV, NRSV, ESV, RSV, etc. 
ior potior, he nevertheless suggests that the hiphil has been used here merely to emphasize the process of conception. ${ }^{46}$ Yet the literal reading of the verse clearly connects the conception of the child to the woman's production of seed. The possibility that Lev 12:2 reflects a notion of female procreative powers has been entertained by Jacob Milgrom, albeit he still understands this in light of menstrual blood, referencing rabbinic texts in which the rabbis held that conception occurred when the woman's blood united with the male semen. ${ }^{47}$ Yet in light of the use of "seed" to describe the offspring of various female characters, the more obvious meaning of זרע is to be preferred: the woman has produced - זרע-not menstrual blood, but "seed" equivalent to that produced by the male, which is to say, semen.

A similar idea seems to be expressed in the book of Ruth. In Ruth 4:12, the elders bless Boaz and his household:

ויהי ביתך כבית פרץ אשר־ילדה תמר ליהודה מן־הזרע אשר יתן יהוה לך מן־הנערה

הזאת ויהי

"May your house become like the house of Perez, whom Tamar bore to Judah, from the seed whom the Lord gives to you from this young woman."

Grammatically, the "seed" comes not from Boaz, but from both God and the young woman, namely Ruth. ${ }^{48}$ The continuation of the story in v. 13 describes how Boaz "took" Ruth, using the 3 ms consecutive preterite of לקח, "to take." This verb can be used in two related senses, to describe the formalization of marriage or as a euphemism for sexual intercourse. This is how the verb is used in

46 Hartley, Leviticus, 165 .

47 Milgrom, Leviticus, 743-44. The connection between conception and menstrual blood is also found in the writings of Philo, who maintains that it is "the remains of the menstrual fluid [that] produces the foetus" (see Quaestiones in Genesim, 3:47; cf. De opificio mundi, 132). Arguably, however, Philo is influenced by Aristotle here, and these passages show affinities with Aristotelian terminology: he has adopted Greco-Roman conceptions in contrast to the earlier biblical ideas-and this is also the case with the later rabbinic writings. On the concept of female seed in the Talmud, see Feldman, Marital Relations, 135-40.

48 In OG, $\mathrm{LXX}^{\mathrm{L}}$ and Theodoret, the Greek reads $\sigma \pi \dot{\varepsilon} p \mu \alpha \tau \circ \varsigma$ $\sigma 0 \mathrm{v}$, "your seed," thus inserting Boaz back into the procreative process. However, this is likely a scribal error triggered by

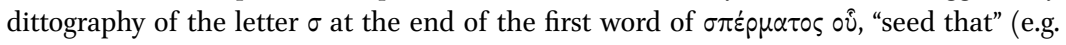
"seed that the Lord will give you"), and most versions, including most Old Greek witnesses, do not support the alternative reading of $\mathrm{OG}, \mathrm{Lxx}^{\mathrm{L}}$ and Theodoret. See Schipper, Ruth, 172. 
Gen 34:2, where Shechem "takes" Dinah; or in Lev 20:14, 17, 21, which describes the union between a man and his mother-in-law, sister, or sister-in-law. Since these unions are condemned they accordingly cannot refer to a legitimate marriage but rather to an (unlawful) sexual union. It is this latter meaning of לקח that some commentators understand here in the book of Ruth, for example in the NET translation of the verse, which describes how Boaz "had sexual relations" with Ruth. On the other hand, according to the NRsv the verse should be interpreted in the conjugal sense: "So Boaz took Ruth and she became his wife." In fact, לקח with the sense of marriage is usually expressed by the idiom לקח לקח ,לאשה thus "to take a wife."49 When לקח is used with a sexual force, as in the examples cited from Genesis and Leviticus above, the verb occurs without the accompanying prepositional phrase functioning as direct object. It is the former construction which is found in Ruth 4:13, and therefore the clause refers to the marriage of Boaz and Ruth rather than to their sexual union. The verse continues:

\section{ויבא אליה ויתן יהוה לה הריון ותלד בן}

He went into her, and the Lord gave her conception, and she bore a son.

Translations of this verse are unanimous in seeing the unspecified subject of the first clause to be Boaz: thus Boaz "went into" Ruth, utilizing the verb בוא, which occurs frequently as an idiom to describe sexual activity. ${ }^{50}$ Yet the next clause describes how Ruth's conception is the direct result of the activity of God, who "gifts" it to her. ${ }^{51}$ In this case, we might interpret the first clause not to refer to the sexual activity of Boaz, but rather make God the subject of the action: he (namely, the Lord) goes to Ruth, and the result of this interaction is the conception and birth of the child. These verses seem to divorce Boaz from the procreative process. ${ }^{52}$ Instead, the birth of Obed stems entirely

$49 \quad$ DCH 4:573.

$5^{\circ} \quad$ See e.g. Gen 16:2; 29:21, 23; 30:4; 38:2; Judg 16:1; 2 Sam 11:4; 12:24; 16:21, 22.

51 The word translated as "conception," הריון, occurs only here and in Gen 3:16 and Hos 9:11. The nominal form derives from the root הרה, "to conceive," with an suffix. In Gen 3:16, God curses the woman with pain in conception; while Hos 9:11 depicts a time of no conception. The term elsewhere therefore relates to ideas of infertility and difficult childbirth, and the unusual form may have been chosen to emphasize the important role of God in gifting a miraculous pregnancy. It is significant that the gifting of the conception is the only action attributed to God in the entire book, emphasizing its importance.

$5^{2}$ This literary strategy may be related to a larger attempt in the book of Ruth to dismantle 
from the procreative work of God and Ruth alone-and in this context, both contribute "seed."

This belief in female seed is corroborated by other biblical texts where conception is linked to specifically female pleasure during intercourse-the idea seems to be exactly equivalent to the later ideas espoused in the Hippocratic writings and by Galen, where female orgasm is necessary to release the woman's seed. In Gen 18:11-13, God appears to announce that Abraham and Sarah will soon be with child:

\title{
ואברהם ושרה זקנים באים בימים חדל להיות לשרה ארח כנשים ותצחק שוֹרה בקרבה

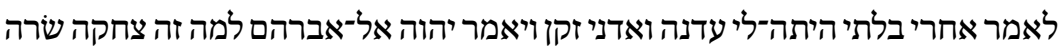

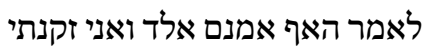

\begin{abstract}
Now Abraham and Sarah were old, advanced in age; it had ceased to be with Sarah after the manner of women. ${ }^{53}$ So Sarah laughed to herself, ${ }^{54}$ saying, "After I have grown old, and my husband is old, shall I have ${ }^{55}$ sexual pleasure?" The Lord said to Abraham, "Why did Sarah laugh, and say, 'Shall I indeed bear a child, now that I am old?'”
\end{abstract}

The feminine noun עדנה, here "sexual pleasure," occurs only here in the Hebrew Bible. The verbal form עדן also occurs only once in biblical literature, meaning "to delight" (Neh 9:25). The related masculine noun מעדן means "delight" (Prov 29:17) and is used to describe edible delicacies (Gen 49:20; Lam 4:5); the masculine noun עדן means "luxury" or "finery" at 2 Sam 1:24 and Ps 36:8.56 The adjectival derivative עדינה may mean something like "voluptuous" or even "pleasure-crazed" in Isa 47:8.57 The semantic range of this field of terminology

conventional wisdom and ideas, such as the ideal of patrilineal descent. See Quick, "The Book of Ruth," 64-65.

53 The expression "the way of women" also occurs in Gen 31:25. In both contexts, it is clearly related to menstruation.

54 Lit. "Sarah laughed in her inward parts." This clearly refers to an internal thought process. See Niehoff, "Do Biblical Characters Talk to Themselves?" $583-85$.

55 The translation of the 3 fs qal perfect of היה, "to be," as "shall I" reflects the interpretation of this verb as an instance of the perfect "to express facts which are undoubtedly imminent, and, therefore, in the imagination of the speaker, already accomplished." See G KC § 106n.

56 See also the גן־בעדן, "garden of Eden," or "garden of delight." The term may also have connotations of "abundant moisture" through this well-watered garden. Following Targum Pseudo-Jonathan, A.A. Macintosh has argued that there was in ancient Hebrew a third root עדה, cognate with Arabic $\dot{g} \underline{d} w$, which means both "fed, nourished," as well as "flowed (of blood or urine)." See "A Third Root," 454-73.

For the translation "pleasure-crazed" see NLT; NAB translates the term as "sensual." 
suggests that עדנה in Gen 18:12 must mean something like "delight" or "pleasure." While the context of conception in Genesis 18 might alone be taken as suggesting that the term refers specifically to sexual delight, this interpretation is corroborated by the Genesis Apocryphon: the cognate Aramaic word עדינה is exactly the term used to describe the pleasure of Bitenosh in 1QapGen ar 2:9, 14, where the word is explicitly connected to panting breath, intercourse and heat.

This reference to Sarah's sexual pleasure has perplexed commentators. Victor Hamilton understands the reference to "pleasure" in the context of the pleasures of parenthood, in so doing making light of the sexual connotations of this word. ${ }^{58}$ Gordon Wenham supposes that as a "decrepit old woman," Sarah could hardly be expected to enjoy sexual pleasure with her husband. ${ }^{59}$ Both possibilities are raised by Sharon Pace Jeansonne, who notes that "one possibility of its meaning is that Abraham never responds sexually to Sarah. Another would be that her infertility has made her life so bleak that pleasure is not possible." ${ }^{\prime 0} \mathrm{But}$ again, the more literal understanding of the verse might be the best one: Sarah refers to sexual pleasure in the context of conception, and this is well understood by God himself, who explicitly interprets this in light of her ability to bear a child in his response to her. ${ }^{61}$ In this context, it is interesting that Sarah is actually attributed the ability to produce seed in the New Testament. In Heb 11:11, we read "By faith also Sarah herself has received the strength to give seed." As in Lev 12:2, the biblical text attributes the production of seed to a female character: $\varkappa \alpha \tau \alpha \beta>\lambda \eta \dot{\nu} \sigma \pi \varepsilon \dot{p} \mu \alpha \tau \sigma \varsigma$ describes the "power to deposit seed." Consequently, many commentators have assumed the text is corrupt and that this line must have originally referred to Abraham. Van der Horst, on the other hand, provides an alternative suggestion, again connecting this to ancient Greek ideas in which women had their own seminal emissions. ${ }^{62}$ Yet given the reference to Sarah's sexual pleasure in the context of conception in Gen 18:12, we might suggest that rather than reflecting Greco-Roman values, the New Testament text is informed by the tradition found already in the Hebrew Bible, in which Sarah herself contributed seed released through sexual pleasure in the conception of Isaac. ${ }^{63}$

58 Hamilton, The Book of Genesis, 13.

59 Wenham, Genesis, 81.

6o Jeansonne, The Women of Genesis, 23.

61 In contrast, von Rad, Genesis, 207, takes pains to note that Sarah's "bluntness" is not reflected in God's speech as a "special nicety" on the part of the deity.

62 van der Horst, "Sarah's Seminal Emission," 287-302.

63 Interestingly, this is in contrast with the conception theory elsewhere forwarded by the New Testament, which generally develops a preformationist understanding in order to stress that it is God alone who provides the $\pi v \varepsilon \hat{\mu} \mu \alpha$ or "Spirit" that animates Jesus, rather 
One further text from the Hebrew Bible may be helpfully interpreted in light of the requirement for female pleasure in the context of conception. Deuteronomy 24:5 provides legislation for a newly married officer in the army:

\section{כי־יקח איש אשה חדשה לא יצא בצבא ולא־יעבר עליו לכל־דבר נקי יהיה לביתו שנה

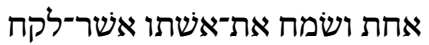

When a man is newly married, he need not go out with the army nor be obligated in any way; he must be free to stay at home for a full year and bring joy to his wife which he has married. ${ }^{64}$

The verb שמח occurs here in the piel stem with the sense of "bring joy to"the idea is clearly that the man will bring "joy" to his wife. In the Syriac this is altered to the simple passive form, thus the man must stay home to "enjoy" his wife. A similar distaste for the M $\mathrm{T}$ is shared by Calum Carmichael, who calls the comment in Deuteronomy unnecessary. ${ }^{65}$ But this misunderstands the intent of the verse in Deuteronomy, which pertains not to any kind of romantic or humanitarian concerns for the officer or his wife, ${ }^{66}$ but instead more likely to the necessity of the officer to produce progeny through which his name and lineage can live on prior to his going out in battle. ${ }^{67}$ In this context, it is necessary for the women to receive "enjoyment" from her husband — the text therefore alludes to the role of female orgasm in conception. ${ }^{68}$

\section{Conception Theory in the Ancient Near East}

The interplay of the passages discussed above suggests that in the world which gave rise to the Hebrew Bible, there was an understanding of the female role in

than any earthly mother or father. Accordingly, Mary is demoted in the procreative process. See Myers, Blessed Among Women?, 42-76.

64 The verse is clearly related to the rules about draft referral found in Deut 20:6-8. On the translation and interpretation of the parallel commandment in Deuteronomy 20, see Quick, "Averting Curses," 220-21.

65 Carmichael, Sex and Religion, 96.

66 Contra Tigay (Deuteronomy, 223), who argues that the law relates to Deuteronomy's "interest in the woman's feelings."

67 The text is explicit that the command only applies to a man who has taken an אשה חדשה, "a new wife," and thus one who is unlikely to have yet produced an heir.

68 Indeed, שמח can also be translated in the sense of conjugal pleasure. See Tigay, Deuteronomy, 223 . 
conception relating to the production of semen and the release of this through orgasm during intercourse. These ideas exist already in biblical literature, and therefore there is no need to derive the source of similar views in the Genesis Apocryphon from the Greco-Roman world-instead the authors of this text may simply be drawing upon earlier biblical ideas and beliefs. In fact, that these ideas developed in the biblical world separately from and in parallel to the Greco-Roman discourse is unsurprising given that similar viewpoints can be found already in the earlier ancient Near Eastern material.

In Mesopotamian literature, as in the Hebrew Bible, it was understood that pregnancy was caused by sexual intercourse, thus a bilingual SumerianBabylonian proverb declares: "Has she become pregnant without intercourse? Has she become fat without eating?"69 Yet there is some controversy in the secondary literature concerning the precise procreative role of the female in relation to the male in the thought world of ancient Mesopotamia. Certainly, the importance of the male is emphasized in ancient Near Eastern texts. Gwendolyn Leick, in her study of sex and eroticism in ancient Mesopotamian literature, accuses these texts of phallocentricism, arguing that they are especially concerned with the fertilizing power of (male) sperm. ${ }^{70}$ Similarly, Stephanie Lynn Budin argues that "in the ancient Near East, it was men who were believed to be the founts of initial fertility ... By contrast, it was women's role to receive that new life, to form it, and to nourish it." ${ }^{71}$ However, in the same way that there existed a diversity of opinions on the topic in the Greco-Roman material, to the extent that later commentators could divide the material between the views of Aristotle and Galen, a similarly diverse set of opinions existed in the ancient Near East. The texts with which Leick and Budin are particularly concerned are derived from the world of mythology, in particular the Sumerian tale of Enki and Ninhursag, in which Enki eats a quantity of his own semen and subsequently becomes impregnated. But making more general extrapolations about the Mesopotamian view of conception on the basis of this particular text risks compounding developments and data from diverse periods. As well as the realm of myth, which arguably presents an idealised view of the world and hence of the process of conception, ${ }^{72}$ medical, diagnostic and therapeutic texts as well as incantations and prayers concerning conception provide addi-

69 Lambert, Babylonian Wisdom Literature, 241, 1l. 40-2; cited in Stol, "Embryology in Babylonia," 137 .

$70 \quad$ Leick, Sex and Eroticism, 49.

71 Budin, "Fertility and Gender," 31.

72 On the problems with using mythological literature to reconstruct Mesopotamian conception theory, see Biggs, "Conception," 1. 
tional data on gynaecological and embryological thought. And here, while the importance of the male is certainly emphasized, the female is by no means considered to be entirely passive in reproduction either.

Indeed, the woman must actively accept the male seed. We find this concept in a variety of texts. BAM 240 is a medical text from Assur, dating to the seventh century вСE. This text describes the conditions of the womb necessary for successful conception:

Diš MUNUS qer-bi-sa re-huu-tam im-hur-ma DUMU.NíTA [Ù.TU] gi-milli [DINGIR] DIŠ MUNUS qer-bi-sa re-hu-tam im-hur-ma NU Ù.TU šib-sat DINGIR NU DÙG-ub [š̀̀] DIŠ MUNUS ina ŠÀ TUKU-at ka-la-a la i-le-'-e ana MUNUS nu-uh-hii GÌR.PAD.DA G[ÍD.DA]

If a woman's womb receives the semen and [she gives birth to] a son, (it means) [divine] favour. If a woman's womb receives the semen and she does not give birth, (it means) divine anger (and) [unhappiness]. If a woman has something in her womb but cannot retain (it), to calm the woman ... ${ }^{73}$

Here the verb mahāru, "to receive, accept," is used to refer to the womb accepting the male seed. Subsequently, the womb must kalû, "retain" it. This perception of the necessity of the womb to "receive" the semen is also found in more literary texts, where "to seize (șabātu) the seed" occurs in a prayer to Sîn. ${ }^{74}$ In these texts, the woman's body is clearly imagined to have an active role in the process of conception. And elsewhere in the medical literature, this active role is explicitly related to the release of her seminal fluid. Thus in a recipe for promoting conception we read:

DIŠ MUNUS NU PEŠ $4 a-n a$ šu-ri-i 4 Ú 4 NINDA.HI.A ŠIM.GÚR.GÚR $1 / 2$ GÍN ŠIM.LI 1 GÍN šam-ba-li-il-tu 1 GÍN ŠE.GIŠ.İ bu-'u-ú-šu-tú 1 GÍN ši-qit-tú ina hu?-li-bi šá KÁ dan-nu HुI.Hु I alla-an DÙ-uš ana ŠÀ.TÙR GAR-ma BAD-ma ir-ri u A.MEš šUB.šUB-ma

73 вам 3 240:69-71. For the text and translation, see Scurlock, Sourcebook, 613, 616.

74 Stol, Birth in Babylonia, 8. In Sumerian literature, there is dispute over the meaning of šu-ti or šu-du $u_{11}$ in the myth of Enlil and Ninlil, where it occurs in connection to female receipt of semen. Thorkild Jacobsen ("The Stele of the Vultures," 247-59) takes the verb to mean "to insert, implant," thus reconstructing a more passive role for the female. Hermann Behrens, on the other hand, interprets the verb with the meaning of "to take, to accept," thus providing precisely the same idea as the Akkadian texts. See Enlil und Ninlil, 133-38. 
In order to make a barren woman pregnant you mix four plants, four (pieces of) bread (?), kukru aromatic, $1 / 2$ shekel of juniper, 1 shekel of fenugreek, 1 shekel of stinking sesame (?), 1 shekel of almonds with fatty material (?) from the mouth of a vat; you make a tampon, insert it in (her) vagina, and she will "open" and will become pregnant and (her) waters will flow. ${ }^{75}$

Ulrike Steinert has considered this text in detail. The text describes the result of the successful administration of the medical recipe: the woman's "waters will flow." There is a difficulty with the precise meaning of the word A.MEš, here "waters." A.MEš can be read logographically for either $m \hat{u}$, "water, fluid," or rihûtu, "semen." to fluids and hence connected the discharge to the loss of amniotic fluid. ${ }^{77}$ Yet this would be a surprising result for a recipe which is supposed to promote a successful conception. Steinert instead proposes that the word be read as rihûtu, and so as a reference to female semen released during intercourse and hence necessary for conception. Accordingly, her translation of the line in question reads "she will repeatedly discharge (her) fluids."78 Indeed, the word for "semen" in Akkadian, rihûtu, is derived from the verb reĥu, "to pour out," thus conveying the idea of a fluid. ${ }^{79}$ Yet while the semantic implications of this terminology likely derive from direct observation of the nature of male seminal fluid, nevertheless in a number of texts rihûtu or semen is attributed to women, strengthening Steinert's interpretation of the gynaecological recipe. ${ }^{80}$ Indeed, Steinert suggests that Babylonian medical writers may have interpreted female discharges by means of analogy to male seminal emissions. A text from the

75 Bм 42333+ obv. 5-11. For the text and translation, see Finkel, "On Late Babylonian Medical Training," 171-73.

76 These two possible readings preclude the interpretation of the female fluid as menstrual blood. Indeed, as Erica Reiner has observed, so far no term in the Babylonian medical literature has been identified for describing the menses. See "Babylonian Birth Prognoses," 129 .

77 See e.g. Scurlock and Andersen, Diagnoses, 731 n. 45.

78 Steinert, "Concepts of the Female Body," 307-10.

79 In contrast to Biblical Hebrew, the Akkadian word for "seed," zeer, rarely means semen (although it can be utilised in the related sense of "offspring" or "progeny"). See Stol, Birth in Babylonia, 4 .

8 E.g., вам 205: 40; K.2453+ (Cт 23, 5-14 rev. iii. 18-19). See Biggs, SA.ZI.GA, 66, 68; and Ebeling, "Keilschrifttafeln medicinischen," 140-44. In a text from Seleucid Borsippa, the constellation Erua is accorded the feminine title "Creatress of Semen," bānât rihûti. See Zee, "A Late Babylonian Astral Commentary," 166. 
Assur Medical Catalogue makes this exact connection: "If (fluids) [flow from] a woman'[s vagina] like semen from the penis ..." 81

These references to female semen in both Mesopotamian and biblical texts are highly intriguing in light of the evidence from the literature of ancient Ugarit. $\mathrm{KTU}^{3} 1.23$ tells the story of the birth of Šahar and Šalim, born of the deity Ilu and two unnamed women:

yhbr.špthm.yšq.hn.špthm.mtqtm.mtqtm.klrmn $[m] . b m . n s ̌ q . w h r . b h b q$. hmmhmt.tqt [nșn.w]tldn.šḥ.wšlm.

He bows down to kiss their lips, Ah! Their lips are sweet, sweet as succulent fruit. In kissing, conception. In embracing, heat. The two travail and give birth to the gods Šahar and Šalim. ${ }^{82}$

The connections between the language of embrace, kissing, and "heat" in the context of conception are shared by another Ugaritic literary text, the tale of Aqhat, where Ilu decrees that Danatiya, wife of Danil, will conceive:

\section{bm.nšq.ațth.hr.tškn.bḥbqh.hmḥmt.}

In kissing his wife, conception! In embracing her, heat!83

In both cases, the "embrace" between husband and wife, in parallel to the language of kissing and in the context of procreative activities, is clearly a euphemism for sexual intercourse. ${ }^{84}$ The word hamhamatu, literally "heat," is surely also euphemistic. The more usual sense of the cognate verb in Hebrew, חמם, means "to be warm." 85 However, it is also used in a sexual sense, for example in Gen 30:38-41, which describes the mating of Jacob's flock. ${ }^{86}$ In Gen 30:39, the consecutive preterite 3mp ויחמו must mean "they mated" rather than "they were in heat," since the next clause in the sentence describes the sheep giving birth. Similarly, in Isa 57:5 the niphal participle mp הנחמים describes the activi-

\footnotetext{
81 Assur Medical Catalogue (fragment A 7821 rev. 8), cited in Steinert, "Concepts of the Female Body," 311 n. 71.

$82 \mathrm{KTU}^{3} 1.23 \cdot 49^{-}{ }^{2}$. For the text and translation, see Lewis, "The Birth of the Gracious Gods," 212.

$83 \mathrm{KTU}^{3}$ 1.17.1.39-40. For the text and translation, see Parker, "Aqhat," 54.

84 Winter, Frau und Göttin, 369 n. 821.

85 See e.g. Ex 16:21; Deut 19:6; 1 Kgs 1:1; 2 Kgs 4:34; Isa 44:15, 16; 47:14; Ezek 24:11; Hos 7:7; Hag 1:6; Job 6:17; 31:20; 39:14; Qoh 4:11; Neh 7:3.

86 Cf. Gen 31:10; Ps 51:7.
} 
ties of certain individuals "under the oaks and every green tree" in the context of the condemnation of various apostate ritual practices, including human sacrifice. The NRSV translation speaks of those who "burn with lust," but the focus on ritual activity suggests translating the term as referring to those "who practice (ritual) sex." ${ }^{87}$ Similarly, the appetites which grow "hot" in Jer 51:39 are probably related to the sexual implications of the verb: it speaks of the desires of the appetite. Thus, the cognate verb in the Hebrew has nuances of heat, sex, desire and conception. Consequently, almost all commentators take the references to hamhamatu in Ugaritic literature to refer to the orgasm of the female ${ }^{88}$ Clearly the production of hamhamatu, "heat," is necessary for the woman to "achieve conception." The active role of the female is also evidenced in the tale of Aqhat through the designation of Danatiya as yālittu, "she who is going to bear," a G active participle fs of the verb $y$ ld. In Ugaritic literature, therefore, women have an active role in the promotion of pregnancy, and sexual pleasure was a necessary prerequisite to this. We might connect this to the idea of the release of female seed, necessitated through orgasm. Just as in the Genesis Apocryphon, in Ugaritic literature female sexual pleasure therefore becomes the sign of successful conception - and using the same language of "heat" shared by the much later Jewish text.

\section{$4 \quad$ Conception Theory in Ancient Judaism}

In this survey of the biblical and ancient Near Eastern material, we have seen a number of examples in which conception was necessitated through specifically female sexual pleasure and the related release of female seed. Though the writers of these texts never developed a systematic statement on conception theory akin to the philosophical writings and medical tractates produced in the Greco-Roman world, they were nevertheless able to develop significant reflections upon the nature of human reproduction. Accordingly, while I agree with Fröhlich and van der Horst that Bitenosh's statements regarding her own sexual

87 Cf. the NET translation.

88 van Selms, Marriage and Family Life, 83; de Moor, An Anthology of Religious Texts, 229 n. 41; Tropper, Ugaritische Grammatik, 494, 565; Margalit, The Ugaritic Poem of AQHT, 282; Wright, Ritual in Narrative, 79. In the case of the tale of Aqhat, Daniel Sivan interprets hmhmt as a qatal 3 fs, translating "she became sexually aroused" (Grammar of the Ugaritic Language, 179), however the term occurs in parallel to $h r$, "conception," which is clearly not a qatal 3 fs verb. Accordingly, Hennie Marsman regards both sentences as nominal clauses, necessitating the translation: "She who is going to bear will ach[ieve conception], orgasm for Sa[viour's man]!" See Women in Ugarit, 459 . 
pleasure are related to an ancient theory of embryogenesis in which this was essential to conception, I reject that this theory can only be derived from GrecoRoman precedents. As we have seen, there is nothing specific in the language or ideas found in the Apocryphon that necessitates connecting it to the GrecoRoman milieu. Rather, conception theory in ancient Judaism is consistent with earlier biblical and ancient Near Eastern views. In fact, the specific connection between the language of "heat" and sexual pleasure is exactly paralleled between the Genesis Apocryphon and the earlier Ugaritic literature, suggesting the Northwest Semitic origins of this idea-and in contrast to the Hippocratic writings, where "heat" is associated with the release of male seed. This connection between "heat," "sex," "pleasure" and "conception" is also evidenced in the Hebrew Bible through the semantic domain of the Hebrew verb חמם, "to grow hot." Conception theory in ancient Judaism may therefore have been informed by and continued earlier biblical theories to do with spermatogenesis and embryology, ideas which developed separately from and in parallel to the Greco-Roman discourse. To relate the theory of conception which informed the Genesis Apocryphon purely to Greek scientific concepts fails to do justice to the ancient medical knowledge developed in and evidenced by the Hebrew Bible.

\section{Bibliography}

Behrens, Hermann. Enlil und Ninlil: ein sumerischer Mythos aus Nippur. Rome: Pontifical Biblical Institute, 1978.

Beyer, Klaus. Die aramäischen Texte vom Toten Meer samt den Inschriften aus Palästina, dem Testament Levis aus der Kairoer Genisa, der Fastenrolle und den alten talmudischen Zitaten. Göttingen: Vandenhoeck \& Ruprecht, 1984.

Biggs, Robert D. SA.ZI.GA: Ancient Mesopotamian Potency Incantations. Locust Valley: Augustin, 1967 .

Biggs, Robert D. "Conception, Contraception, and Abortion in Ancient Mesopotamia." Pages 1-13 in Wisdom, Gods and Literature: Studies in Assyriology in Honour of W.G. Lambert. Edited by Andrew R. George and Irving L. Finkel. Winona Lake: Eisenbrauns, 2000 .

Blayney, Jan. "Theories of Conception in the Ancient Roman World." Pages 230-36 in The Family in Ancient Rome: New Perspectives. Edited by Beryl Rawson. London: Routledge, 1986.

Boylan, Michael. "The Galenic and Hippocratic Challenges to Aristotle's Conception Theory." Journal of the History of Biology 17 (1984): 83-112.

Boylan, Michael. "Galen's Conception Theory." Journal of the History of Biology 19 (1986): 47-77. 
Budin, Stephanie Lynn. "Fertility and Gender in the Ancient Near East." Pages 30-49 in Sex in Antiquity: Exploring Gender and Sexuality in the Ancient World. Edited by Mark Masterson, Nancy Sorkin Rabinowitz and James Robson. London: Routledge, 2015.

Carmichael, Calum. Sex and Religion in the Bible. New Haven: Yale University Press, 2010.

Chapman, Cynthia R. “'Oh That You Were Like a Brother to Me, One Who Had Nursed at my Mother's Breasts.' Breast Milk as a Kinship-Forging Substance." JHS 12 (2012):1-41.

Connell, Sophia M. "Aristotle and Galen on Sex Difference and Reproduction: A New Approach to an Ancient Rivalry." Stud.Hist.Phil.Sci. 31 (2000): 405-27.

Douglas, Mary. Purity and Danger: An Analysis of Pollution and Taboo. New York: Routledge, 1966.

Ebeling, E. "Keilschrifttafeln medicinischen Inhalts I." AGM 13 (1921): 138-44.

Erbele-Küster, Dorothea. Body, Gender, and Purity in Leviticus 12 and 15. Lнвотs 539. London: Bloomsbury, 2017.

Eshel, Esther. "The Imago Mundi of the Genesis Apocryphon." Pages 111-31 in Heavenly Tablets:Interpretation, Identity and Tradition in Ancient Judaism. Edited by Lynn LiDonnici and Andrea Lieber. JsJs 119. Leiden: Brill, 2007.

Feldman, David M. Marital Relations, Birth Control, and Abortion in Jewish Law. New York: Schocken, 1974.

Finkel, Irving L. "On Late Babylonian Medical Training." Pages 137-224 in Wisdom, Gods and Literature: Studies in Assyriology in Honour of W.G. Lambert. Edited by Andrew R. George and Irving L. Finkel. Winona Lake: Eisenbrauns, 2000.

Fitzmyer, Joseph A. The Genesis Apocryphon of Qumran Cave 1: A Commentary. 2nd edn. Rome: Pontifical Biblical Institute, 1971.

Flynn, Shawn W. Children in Ancient Israel: The Hebrew Bible and Mesopotamia in Comparative Perspectives. Oxford: Oxford University Press, 2018.

Fröhlich, Ida. "Medicine and Magic in Genesis Apocryphon: Ideas on Human Conception and its Hindrances." RevQ 98 (2011): 177-98.

Hamilton, Victor P. The Book of Genesis: Chapters 18-50. Grand Rapids: Eerdmans, 1995. Hartley, John E. Leviticus. WBC 4. Dallas: Word Books, 1992.

Henriksen Garroway, Kristine. Growing Up in Ancient Israel: Children in Material Culture and Biblical Texts. ABs 23. Atlanta: SBL, 2018.

Horst, Pieter W. van der. "Sarah's Seminal Emission: Hebrews 11:11 in the Light of Ancient Embryology." Pages 287-302 in Greeks, Romans, and Christians: Essays in Honor of Abraham J. Malherbe. Edited by David L. Balch et al. Minneapolis: Fortress, 1990.

Horst, Pieter W. van der. "Bitenosh's Orgasm (1QapGen 2:9-15)." JSJ 43 (2012): 613-28.

Horst, Pieter W. van der. "Early Jewish Knowledge of Greek Medicine.” Pages 103-14 in Strength to Strength: Essays in Appreciation of Shaye J.D. Cohen. Edited by Michael Satlow. BJs. Providence: Brown University, 2018.

Jacobsen, Thorkild. "The Stele of the Vultures Col. I-X." Pages 247-59 in Kramer 
Anniversary Volume: Cuneiform Studies on Honor of Samuel Noah Kramer. Edited by Barry L. Eicler, Jane W. Heimerdinger and Åke W. Sjöberg. AOAT 25. NeukirchenVluyn: Neukirchener Verlag, 1976.

Jastrow, Marcus. Dictionary of the Targumim, Talmud Babli, Yerushalmi and Midrashic Literature. London: Luzac \& Co., 1903.

Jeansonne, Sharon Pace. The Women of Genesis: From Sarah to Potiphar's Wife. Minneapolis: Fortress, 1990.

Kugel, James. "Which is Older, Jubilees or the Genesis Apocryphon? An Exegetical Approach." Pages 257-94 in Dead Sea Scrolls and Contemporary Culture. Edited by Adolfo D. Roitman et al. sTDJ 93. Leiden: Brill, 2011.

Lambert, W.G. Babylonian Wisdom Literature. Oxford: Clarendon, 196o.

Laqueur, Thomas. Making Sex: Body and Gender from the Greeks to Freud. Cambridge: Harvard University Press, 1990.

Leick, Gwendolyn. Sex and Eroticism in Mesopotamian Literature. London: Routledge, 1994.

Lesky, Erna. Die Zeugungs- und Vererbungslehre der Antike und ihre Nachwirkung. AGS K 19. Wiesbaden: Franz Steiner Verlag, 1951.

Levine, Baruch. “'Seed' versus 'Womb': Expressions of Male Dominance in Biblical Israel." Pages 337-44 in Sex and Gender in the Ancient Near East. Edited by Simo Parpola and R.M. Whiting. Helsinki: Neo-Assyrian Text Corpus Project, 2002.

Lewis, Theodore J. "The Birth of the Gracious Gods." Pages 205-14 in Ugaritic Narrative Poetry. Edited by Simon B. Parker. Atlanta: Scholars Press, 1997.

Loader, William. The Dead Sea Scrolls on Sexuality: Attitudes to Sexuality in Sectarian and Related Literature at Qumran. Grand Rapids: Eerdmans, 20o9.

Machiela, Daniel A. The Dead Sea Genesis Apocryphon: A New Text and Translation with Introduction and Special Treatment of Columns 13-17. Leiden: Brill, 2009.

Machiela, Daniel A. "Genesis Revealed: The Apocalyptic Apocryphon from Qumran Cave 1." Pages 205-21 in Qumran Cave 1 Revisited: Texts from Cave 1 Sixty Years after Their Discovery. Edited by Daniel K. Falk et al. STDJ 91. Leiden: Brill, 2010.

Macintosh, A.A. “A Third Root עדה in Biblical Hebrew?" VT 24 (1974): 454-73.

Margalit, Baruch. The Ugaritic Poem of AQH T: Text, Translation, Commentary. BZAW 182. Berlin: de Gruyter, 1989.

Marsman, Hennie J. Women in Ugarit and Israel: Their Social and Religious Position in the Context of the Ancient Near East. Leiden: Brill, 2003.

McLaren, Angus. "The Pleasures of Procreation: Traditional and Biomedical Theories of Conception." Pages 323-41 in William Hunter and the Eighteenth-Century Medical World. Edited by W.F. Bynum and Roy Porter. Cambridge: Cambridge University Press, 1985 .

Merleau, Chloë Taylor. "Bodies, Genders and Causation in Aristotle's Biological and Political Theory." Ancient Philosophy 23 (2003): 135-51. 
Milgrom, Jacob. Leviticus 1-16: A New Translation and Commentary. AB 3. New York: Doubleday, 1991.

Moor, Johannes C. de. An Anthology of Religious Texts from Ugarit. Leiden: Brill, 1987.

Moss, Candida R. and Joel S. Baden. Reconceiving Infertility: Biblical Perspectives on Procreation and Childlessness. Princeton: Princeton University Press, 2015.

Myers, Alicia D. Blessed Among Women? Mothers \& Motherhood in the New Testament. Oxford: Oxford University Press, 2017.

Nickelsburg, George W.E. "Patriarchs Who Worry About Their Wives: A Haggadic Tendency in the Genesis Apocryphon." Pages $137-5^{8}$ in Biblical Perspectives: Early Use and Interpretation of the Bible in Light of the Dead Sea Scrolls. Edited by Michael E. Stone and Esther G. Chazon. STDJ 28. Leiden: Brill, 1998.

Niehoff, Maren. "Do Biblical Characters Talk to Themselves? Narrative Modes of Representing Inner Speech in Early Biblical Fiction." JBL 111 (1992): 583-85.

Olyan, Saul M. "Mary Douglas's Holiness/Wholeness Paradigm: Its Potential for Insight and its Limitations." JHS 9 (2008): 1-8.

Parker, Simon B. "Aqhat." Pages $49-81$ in Ugaritic Narrative Poetry. Edited by Simon B. Parker. Atlanta: Scholars Press, 1997.

Peck, A.L. Aristotle: Generation of Animals. Loeb Classical Library 366. Cambridge: Harvard University Press, 1942.

Popović, Mladen. Reading the Human Body: Physiognomics and Astrology in the Dead Sea Scrolls and Hellenistic-Early Roman Period Judaism. STDJ 67. Leiden: Brill, 2007.

Presti, Roberto Lo. "Informing Matter and Enmattered Forms: Aristotle and Galen on the 'Power' of the Seed." British Journal for the History of Philosophy 22 (2014): 920-50.

Qimron, Elisha. The Dead Sea Scrolls: The Hebrew Writings. 3 vols. Jerusalem: Yad Ben Zvi, 2010.

Quick, Laura. "Lamech's Change of Mind: The Hellenistic Philosophy Behind the Use of שנא in the Genesis Apocryphon and the Book of Daniel." Aram.St. 11 (2013):53-66.

Quick, Laura. "Averting Curses in the Law of War (Deuteronomy 20)." ZAW 132 (2O2O): 209-23.

Quick, Laura. "The Book of Ruth and the Limits of Proverbial Wisdom." JBL 139 (2020): 47-66.

Rad, Gerhard von. Genesis: A Commentary. Rev. ed. London: Sсм, 1972.

Rashkow, Ilona. Taboo or Not Taboo: Sexuality and Family in the Hebrew Bible. Minneapolis: Fortress, 2000.

Reiner, Erica. "Babylonian Birth Prognoses." zA 72 (1982): 124-38.

Rouselle, Aline. Porneia: On Desire and the Body in Antiquity. Oxford: Blackwell, 1988.

Schipper, Jeremy. Ruth: A New Translation with Introduction and Commentary. AB $7 \mathrm{D}$. New Haven: Yale University Press, 2016.

Scurlock, JoAnn. Sourcebook for Ancient Mesopotamian Medicine. Writings from the Ancient World. Atlanta: S BL, 2014. 
Scurlock, JoAnn and Burton R. Andersen. Diagnoses in Assyrian and Babylonian Medicine: Ancient Sources, Translations, and Modern Medical Analysis. Urbana: University of Illinois Press, 2005 .

Selms, A. van. Marriage and Family Life in Ugaritic Literature. Pos 1. London: Luzac and Co., 1954.

Sivan, Daniel. A Grammar of the Ugaritic Language. Leiden: Brill, 2001.

Sokoloff, Michael. A Dictionary of Jewish Palestinian Aramaic. Ramat Gan: Bar Ilan University Press, 1990.

Steinert, Ulrike. "Concepts of the Female Body in Mesopotamian Gynaecological Texts." Pages 307-10 in The Comparable Body: Analogy and Metaphor in Ancient Mesopotamian, Egyptian, and Greco-Roman Medicine. Edited by John Z. Wee. Leiden: Brill, 2017.

Stiebert, Johanna. "Human Conception in Antiquity: The Hebrew Bible in Context." TSE 16 (2010): 209-27.

Stol, Marten. Birth in Babylonia and the Bible: Its Mediterranean Setting. Cuneiform Monographs 14. Groningen: Styx, 2000.

Stol, Marten. "Embryology in Babylonia and the Bible." Pages 137-56 in Imagining the Fetus: The Unborn in Myth, Religion, and Culture. Edited by Jane Marie Law and Vanessa R. Sasson. Oxford: Oxford University Press, 2009.

Stuckenbruck, Loren T. "The Lamech Narrative in the Genesis Apocryphon (1QapGen) and 1Enoch 106-107: A Tradition-Historical Study of Two Ancient Accounts of Noah's Birth." Pages 58-77 in The Myth of Rebellious Angels: Studies in Second Temple Judaism and New Testament Texts. Tübingen: Mohr Siebeck, 2014.

Tigay, Jeffrey H. Deuteronomy: The Traditional Hebrew Text with the New JPs Translation. Philadelphia: The Jewish Publication Society, 1996.

Tropper, Josef. Ugaritische Grammatik. AOAT 273. Münster: Ugarit-Verlag, 2000.

Warren-Rothlin, Andy. "Euphemism and Bible Translations." Pages 865-69 in Encyclopedia of Hebrew Language and Linguistics, Vol. 1: A-F. Edited by Geoffrey Khan. Leiden: Brill, 2013.

Wenham, Gordon. Genesis 16-50. WвC 2. Dallas: Thomas Nelson, 2000.

Whitekettle, Richard. "Levitical Thought and the Female Reproductive Cycle: Wombs, Wellsprings, and the Primeval World." vT 46 (1996): 376-91.

Winter, Urs. Frau und Göttin: Exegetische und ikonographische Studien zum weiblichen Gottesbild im Alten Israel und in dessen Umwelt. ово 53. Freiburg: Schweiz, 1983.

Wright, David P. Ritual in Narrative: The Dynamics of Feasting, Mourning, and Retaliation Rites in the Ugaritic Tale of Aght. Winona Lake: Eisenbrauns, 2001.

Zee, John W. "A Late Babylonian Astral Commentary on Marduk's Address to the Demons." JNES 75 (2016): 127-67. 